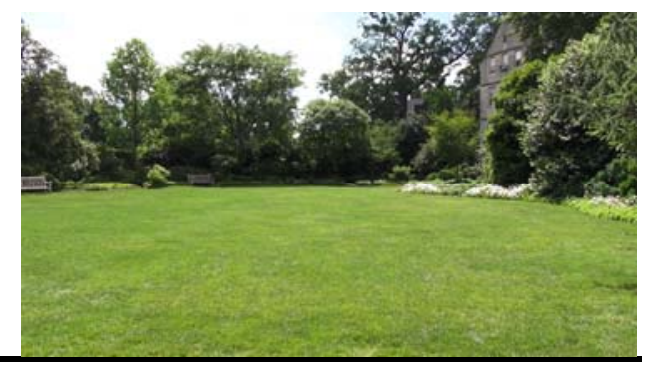

DOI: 10.21005/pif.2016.25.D-01

\title{
THERAPEUTIC GARDEN DESIGN FOR PATIENTS WITH NEURODEGENERATIVE DISEASES
}

\author{
OGRODY TERAPEUTYCZNE DLA PACJENTOW \\ Z CHOROBAMI NEURODEGRADACYJNYMI
}

\author{
Agnieszka Anna Olszewska \\ dr inż. arch. kraj. \\ University of Porto, Portugal \\ Faculty of Science \\ Department of Geosciences, Environment and Spatial Planning
}

Jakub S. Bil

dr inż. arch.

Andrzej Frycz Modrzewski Kraków University

Faculty Architecture and Fine Arts

\section{STRESZCZENIE}

Niniejszy artykuł omawia koncepcję ogrodów terapeutycznych przy ośrodkach opieki dla pacjentów z chorobami neurodegeneracyjnymi, takimi jak choroba Alzheimera i demencje. Opisano sposób, w jaki projektowanie takich przestrzeni może wyjść na przeciw specyficznym potrzebom mieszkańców i opisuje najnowsze badania dotyczące wytycznych dla projektowania ogrodów w pobliżu szpitali, ośrodków medycznych i domów spokojnej starości. Przegląd literatury zestawiono z wynikami najnowszych badań na temat wpływu różnych rozwiązań zaprojektowanych w krajobrazie na aktywność mózgu. Zgodnie z tymi badaniami, przestrzenie charakteryzujące się zgodnością projektu, przejrzystym systemem komunikacji i sygnalizacji, wprowadzeniem elementów archetypowych oraz nacisk na szereg wizualnych niuansów, moga być szczególnie korzystne dla pacjentów $z$ chorobami neurodegeneracyjnymi.

Słowa kluczowe: Alzheimer, architektura, demencja, krajobrazu, neurodegeneracyjne, ogrody, projektowanie, terapeutyczne. 


\begin{abstract}
This paper explores the concept of therapeutic gardens surrounding healthcare institutions treating neurodegenerative diseases, such as Alzheimer's and Dementias. It focuses on how the design of such spaces can address the specific needs of residents, and describes the recent studies concerning the most relevant guidelines for therapeutic garden design near hospitals, medical centers, and retirement homes. The literature study is compared with results of our recent study on the brain response to different landscapedesign features. According to which an outdoor space with a high level of design compatibility, inward space composition, a clear communication and signage system, while introducing archetypal elements and factoring several visual nuances, can be especially beneficial for patients with neurodegenerative diseases.
\end{abstract}

Keywords: Alzheimer's, architecture, dementia, design, garden, landscape, neurodegenerative, therapeutic.

\title{
1. INTRODUCTION
}

Neurodegenerative diseases are characterized by molecular changes in nerve cells that lead to the loss of functions of neurons, progressive loss of neurons, and their death [22]. A variety of symptoms lead to neural dysfunction, resulting in emotional, cognitive, and social behavior impairment [34][23]. The patient's behavioral patterns are represented by a set of symptoms that are, in many cases, the same for mental disorders. For this reason, the patient might often be misdiagnosed [30]. Usually patients are delusional, hallucinating, while exhibiting strange, destructive and aggressive behaviors and, for example, suffer from sleep cycle deprivation and wandering [26].

Environment plays a crucial role in the treatment of patients with neurodegenerative diseases as well as other mental health disorders. The quality of space as a system of interconnected features is determined by the functional arrangement of elements, materials, and strategies utilized by a designer. Depending on the type of disease, different therapeutic priorities should be considered and addressed through the design. The specificity of spatial solutions for patients suffering from neurodegenerative diseases requires various structures, in terms of the scale of the entire space as well as individual wards, interiors, and their equipment. Both patient stress management and improvement of the quality of life are the basic aims that can be achieved through the design of the indoor as well as the outdoor environment. A properly designed outdoor environment can have a tremendous contribution to alleviating the effects of diseases through stress reduction and improvement of the sense of well-being for patients and staff of healthcare units.

The design of environment for patients with neurodegenerative diseases should be adjusted to their behavioral patterns and focused on stress reduction. The pace of development of the disease plays an important role as well. Neurodegenerative diseases mostly develop slowly, across decades, and lead to impairment in numerous aspects of life of an individual, and finally to death. However, sometimes the development of the disease is much faster, and its intensity not equally severe. That is why the space should be prepared in a way that would be suitable for patients representing all different stages of development of neurodegenerative diseases, i.e., those whose disease is in the early stage and those who need to be assisted in their everyday life.

The following pages explain how the values of the outdoor space and their proper use by the designer can, directly or indirectly, contribute to the mental health and well-being of the residents of healthcare units. All the described physical attributes of space have been supported by scientific evidence and fall under the concept of evidence-based design [7]. 


\section{NEURODEGENERATIVE DISEASES - BASIC STATS}

The most common factor of neurodegenerative diseases is aging. It is the main risk factor [13] especially for neurodegenerative diseases of the Central Nervous System that often cause dementia [8][24]. Dementia is a leading cause of mortality and morbidity, especially in developing countries, and about $66 \%$ of all deaths every day are related to conditions of dementia [16][11][18]. More than $50 \%$ of people over 85 years of age suffer from dementia, between 75 and 84 years of age $-19 \%$ and between $65-74$ nearly $3 \%$. The spectrum of dementia includes several conditions such as: Alzheimer's Disease - AD - 50\%$70 \%$ of all cases [10], Vascular Dementia - VD - 25\%, Dementia with Levi bodies -DLB $15 \%$, and others [12] [9]. In DSM V, dementia is classified as a neurocognitive disease [1] and in ICD-10 classified as F00 - F09 (ICD-10/F: Mental and behavioral disorders). Neurodegenerative diseases are classified in ICD-10 as G30-G32: Other degenerative diseases of the nervous system [31].

The most widely applied pharmacotherapy has shown limited benefits in longer term treatment [3]. Moreover, concerns are growing over their serious side effects, which include stroke and death. Therefore, providing a possibility of a non-pharmacological approach to alleviate the symptoms of neurodegenerative diseases is very important. There is increasing evidence in support of alternative therapies, such as exposure to therapeutic gardens.

\section{GENERAL OBJECTIVES OF HEALING GARDENS}

Charm of natural scenery is an influence of the highest curative value; highest, if for no other reason, because it acts directly upon the highest functions of the system, and through them upon all below, tending, more than any single form of medication we can use, to establish sound minds in sound bodies [6].

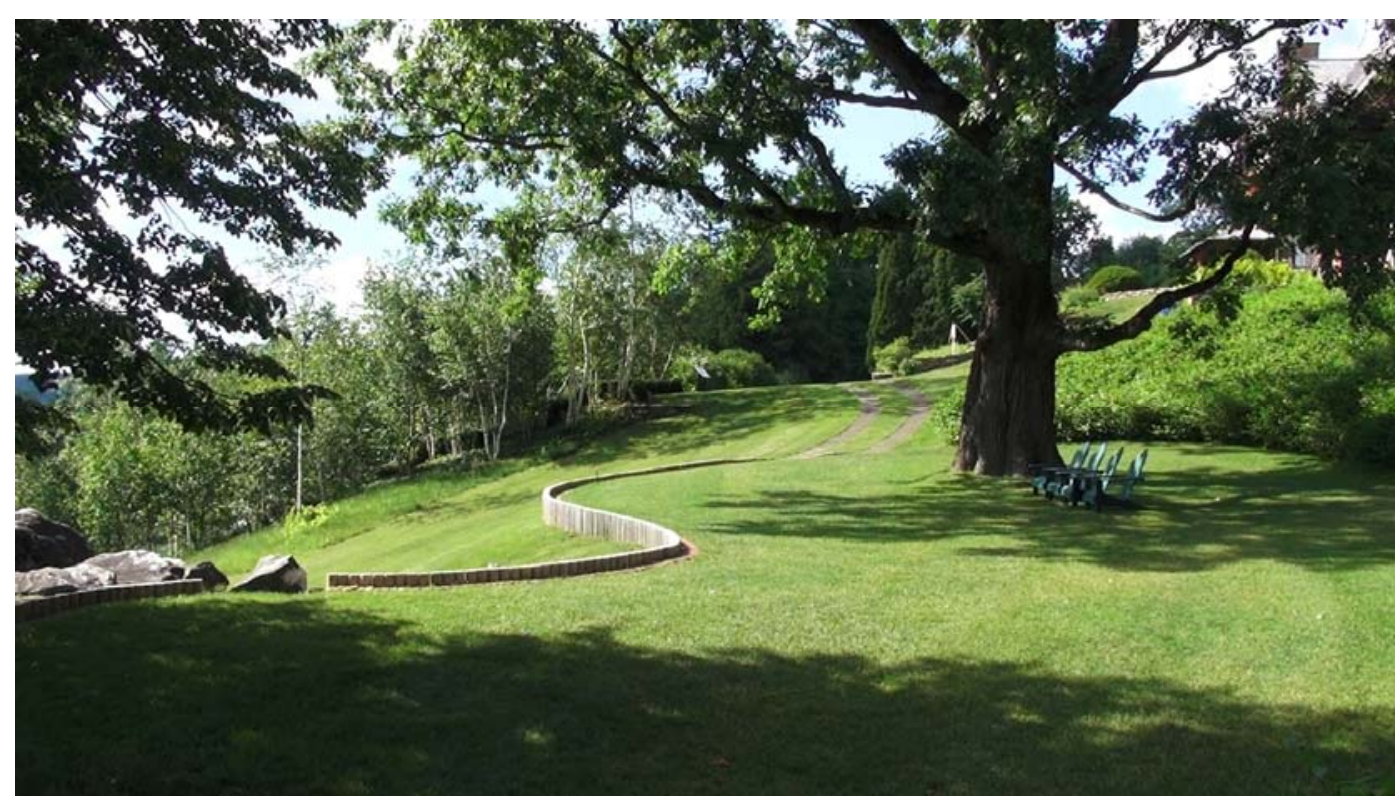

Ryc. 1. Widok na strefę wypoczynku, Naumkaeg Estate, Berkshires, Massachusetts / USA. Projekt Fletcher Steele, Źródło: fotografia A.A. Olszewska wykonana w czerwcu 2014 r.

Fig. 1. A view over the resting area at the Naumkaeg Estate, Berkshires, Massachusetts / USA. Design by Fletcher Steele. Source: photo by A.A. Olszewska, June, 2014. 
It is clear that the environment around us affects behavior as long as we can perceive it. Disciplines such as environmental psychology, architecture, and landscape architecture are increasingly interested in using scientific tools in order to explore the relationship between different elements of the designed space and our behavioral-psychological response. Fletcher Steele's project (Fig. 1) presents an example of a space that, according to recent studies on contemplative landscapes, was ranked by experts as the highest in contemplative values 5.13 points in 1-6 Likert scale [21]. The evaluated factors included the contribution of the following key-components to the overall contemplativeness of the photograph: Landscape Layers, Landform, Vegetation, Compatibility, Color and Light, Archetypal Elements, and Character of Peace and Silence. The garden view from the Figure 1, in a later EEG experiment, induced in the brain activity of observers patterns associated with positive emotions and attention restoration, compared with the landscape images classified as non-contemplative [21]. The Naumkaeg Estate in Berkshires, Massachusetts is a good example of what quality of design would be recommended in order to achieve mental restoration in the people exposed to it.

Studies on the etiology of Alzheimer suggest that the built environment, including contact with nature through the exposition to gardens, can play an important role in alleviating the effects of the disease [33]. The direct aims to achieve are connected with the health benefits of patients, including the diminishment of behavioral disorders, such as agitation, aggressive behavior and aimless wandering, better sleep, improved general health and nutritional status. These indirectly lead to improvements in the well-being of staff members and savings for the management of the institution (e.g., limiting the number of supervising staff employees).

While it may be difficult to predict patient response to the specific event or space, it is possible to set up preliminary conditions for a therapeutic environment. The outdoor space linked with the health-care unit, where patients have contact with fresh air, sunshine, and vegetation, seems to be a very promising area to implement design solutions that enhance people's mental capacities by including some contemplative design strategies. However, in the literature, those gardens prepared specifically for improving the well-being of patients are called therapeutic or healing gardens.

Their main objectives besides contact with nature, with all its restorative benefits, is to stimulate physical exercise in a pleasant, familiar and secure environment, and encouragement of self-managed exploration, while being stimulating and challenging to increase mental alertness. They also promote a sense of independence and provide reduction of stressors.

\section{PRESENCE AND ACCESSIBILITY}

The most obvious and most important way for the therapeutic garden to benefit patients is, of course, its presence as a space attached to the institution where they reside. Most of the retreats provide some outdoor space, however rarely, designed to meet special therapeutic criteria. Due to the lack of a proper design, and lack of constant staffsupervision, the outdoor space is accessible for patients only according to a certain schedule, which limits their independence. The study from Marlborough Alzheimer's healing garden [33] (Fig. 2) showed the therapeutic effect of the mere fact that the residents have the opportunity to come and go to the garden as they please. In the proper design of such spaces, it is very important for it to be safe and fully accessible at least during the daytime.

\section{COMPATIBILITY OF DESIGN AS A THERAPEUTICAL ELEMENT}

In any landscape design, compatibility plays a vital role, and according to the recent study, it contributed most significantly to the overall contemplativeness of tested views 
(Item-Total Corr. =.831). It is identical to the Adjacent Scenery feature of the VRM model [29]. It is about the quality of the design in terms of balance and harmony. Basic premises of compatibility are:

- explicit spatial order, keeping the design in balance;

- absence of disturbing elements;

- openings and closings of views worked out well;

- harmonious physical and visual relations between the elements;

- a clear communication system and hierarchical relations between signage elements

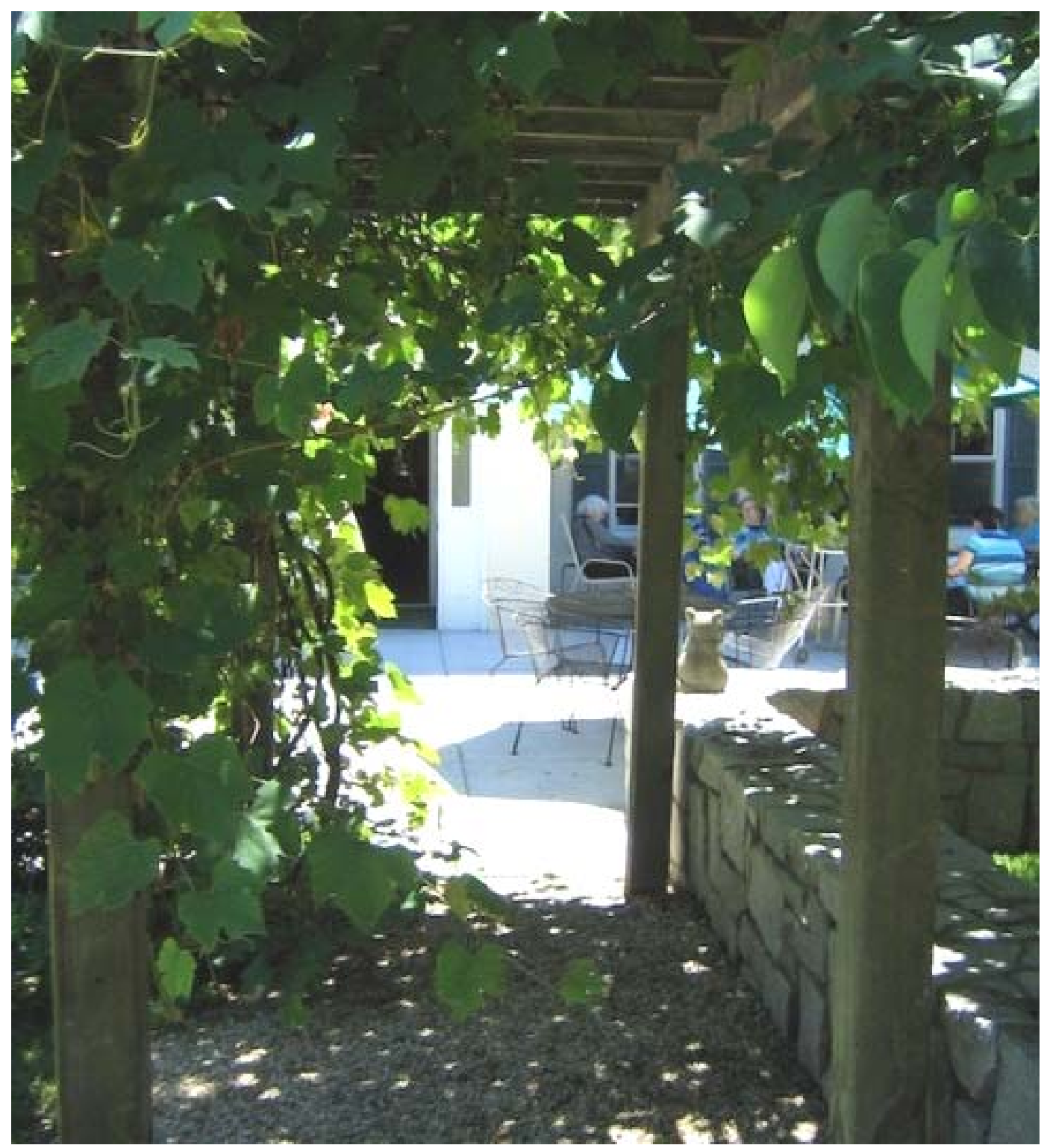

Ryc. 2. Ogród terapeutyczny przy ośrodek opieki nad osobami z chorobą Alzheimera Hearthstone, Marlborough, Massachusetts, Źródło: fotografia, Naomi Sachs [27]

Fig. 2. Therapeutic garden at theHearthstone Alzheimer's Care, Marlborough, MA. Photo by Naomi Sachs [27]. 
As to ensure the high level of compatibility in the enclosed space, inward composition is recommended, where all elements are organized around one clear center. The example presented in Fig. 3 shows the enclosed space with an inward composition, which also scored high in terms of compatibility in the Contemplative Landscapes Expert evaluation 4,8 points in 1-6 Likert scale [21]. This inward composition of space can also be manifested through a clear signage system, which is very important for avoiding the feeling of being lost in space.

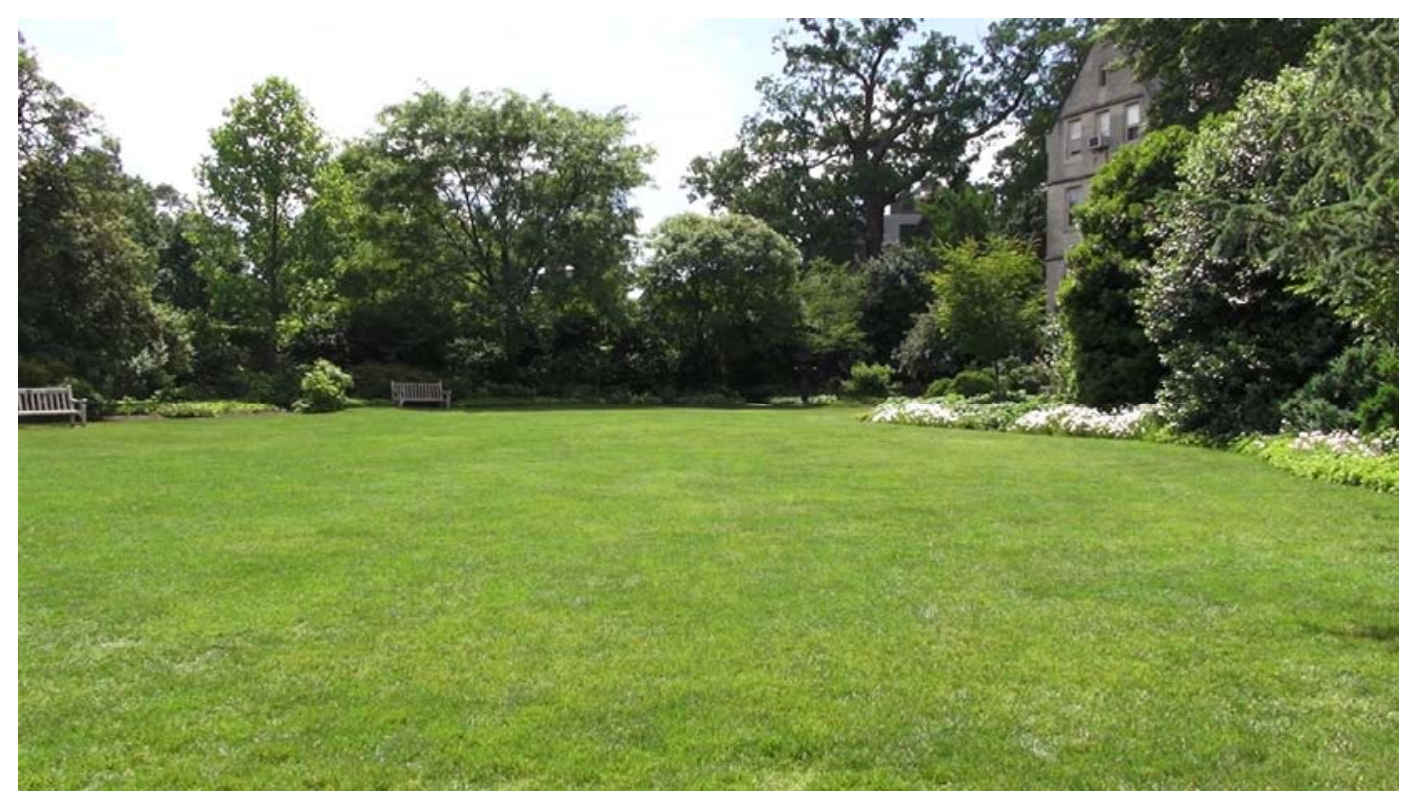

Ryc. 3. Trawnik otoczony nasadzeniami, Ogrody Biskupie przy katedrze w Waszyntonie, Washington D.C, USA Źródło: fotografia A.A. Olszewska wykonana w lipcu 2014

Fig. 3. Large lawn area in Bishop's Garden with an inward orientation of space composition. National Cathedral, Washington D.C., USA. Photo by A.A. Olszewska, July 2014.

Designs with a high level of compatibility can provide a soothing experience to the person exposed to them. The lack of distracting stimuli, intruding the tranquility of the space, can create a ground for restoring one's attention capacities and reduce the level of stress [16].

\section{WAY FINDING AND LANDMARKS}

Being lost can be terrifying. Fears of getting lost can contribute to people's decisions to avoid unfamiliar natural settings. By contrast, feeling reassured that one will be able to find one's way can increase the quality and potential benefits of nature experiences [16, p. 49].

Neurodegenerative conditions often cause patients to get lost even in familiar places. This is due to visuospatial disorientation with impaired optic flow perception, and is one of the earliest clinical manifestations of a disease. Getting lost can cause anxiety and agitation, diminish the effectiveness of applied therapy, and put people's safety at risk [28].

The environmental features associated with both reduced aggressive and agitated behavior include the ambient environment that residents can understand [32 p. 709].

Simplicity and clarity of the landscape design can significantly facilitate patients' spatial orientation and navigation skills. Spaces with a clear, intuitive design, where it is very dif- 
ficult to get lost, can also be called naturally-mapped environments [20]. These spaces are characterized by very few pathways visible from anywhere around the space with clear entrances and exits, and with well-considered accessibility expressed through the ground cover. Fig. 4 presents an example of distinction of the area that should not be accessed by covering it with stones.

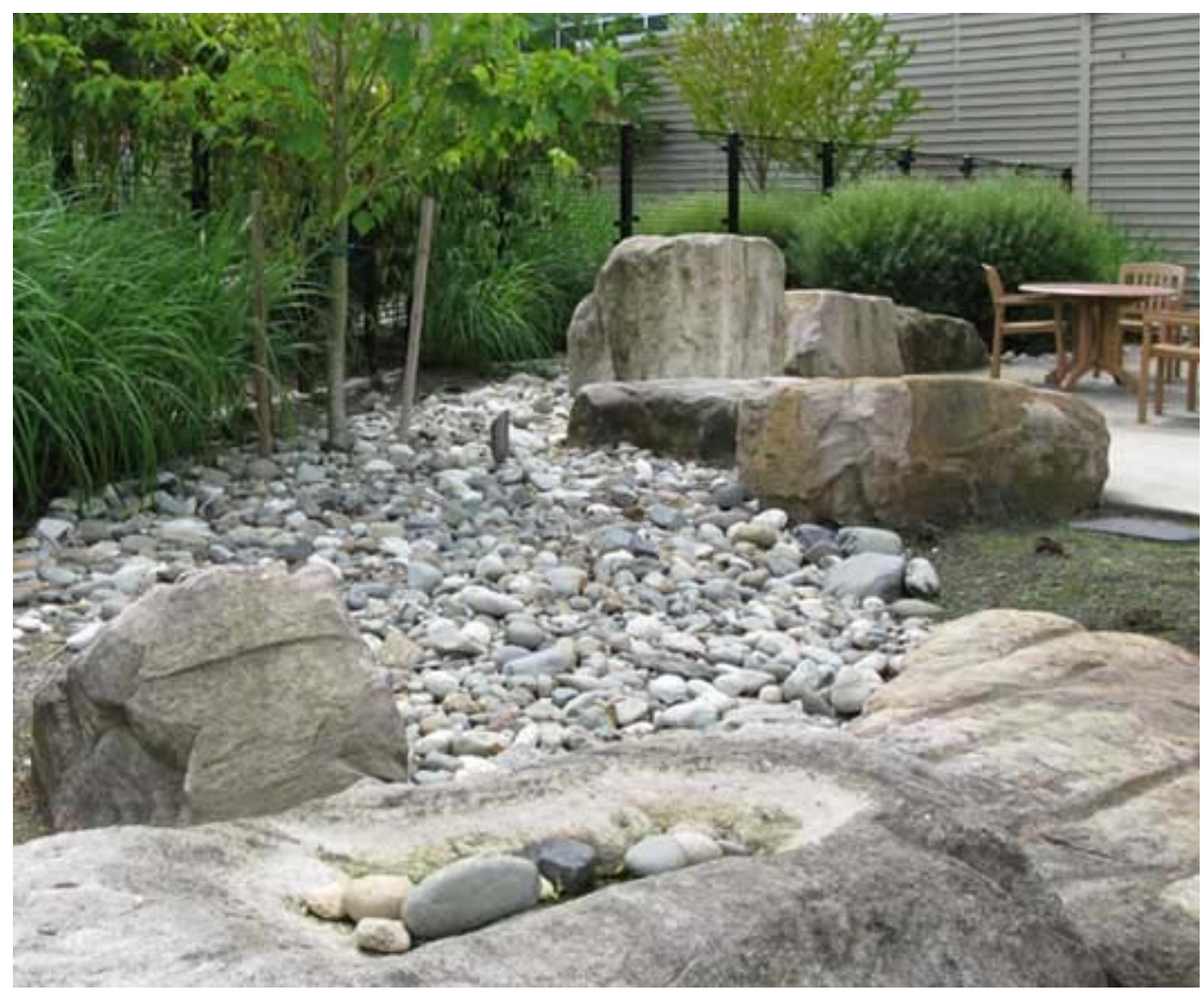

Ryc. 4. Ogród terapeutyczny przy szpitalu Overlake, Bellevue, Washington, USA Źródło: fotografia John Souza [27].

Fig. 4. Therapeutic garden at the Overlake Hospital, Bellevue, WA, USA, Photo by John Souza [27].

An important part of way finding is associated with introducing landmarks in the space. Landmarks are the reference points singled out from other elements in a setting. They play a central role in how people develop their cognitive maps [19, p. 48]. The landmarks in the therapeutic gardens can be architectural elements, such as a wooden shelter, bridge or tower, or elements originating from nature, for example, a single old tree, water feature or big stone. The studies about landscapes of contemplation showed that the scarce elements in the landscape, originating from nature, play the role of archetypal elements that are familiar to everyone on a deep psychological level. They can be powerful, meaningful and symbolically-charged elements, evoking memories, (both personal and more general), eliciting recognition, and inducing contemplation [14, p. 61].

According to Jungian dream analysis, archetypal elements can evoke a strong, unconscious, emotionally-charged response and attraction [15]. For example, one seeing a hill wants to climb it, seeing a water mirror or an old branched oak, one wants to be closer to it. Utilizing natural archetypal elements in therapeutic gardens is important for two major 
reasons: to help enhance the naturally-mapped environments with landmarks and to make patients feel even more familiar with the space (on a deeper, unconscious level).

\section{VISUAL ASPECT}

One of the bases of Attention Restoration Theory (ART) is that natural environments provide the involuntary type of attention:

in involuntary attention... attention is captured by inherently intriguing or important stimuli, and in voluntary or directed attention, ... attention is directed by cognitive-control processes [5, p. 16].

Landscapes classified by environmental psychologists as "natural" do not demand concentration or focus on details, therefore they enable a decrease of stress level as well as regulate emotions, anxiety and mental fatigue.

An important aspect of the visual character of the therapeutic garden are views in the different distance zones that it provides (see Fig. 5).

\section{Background}

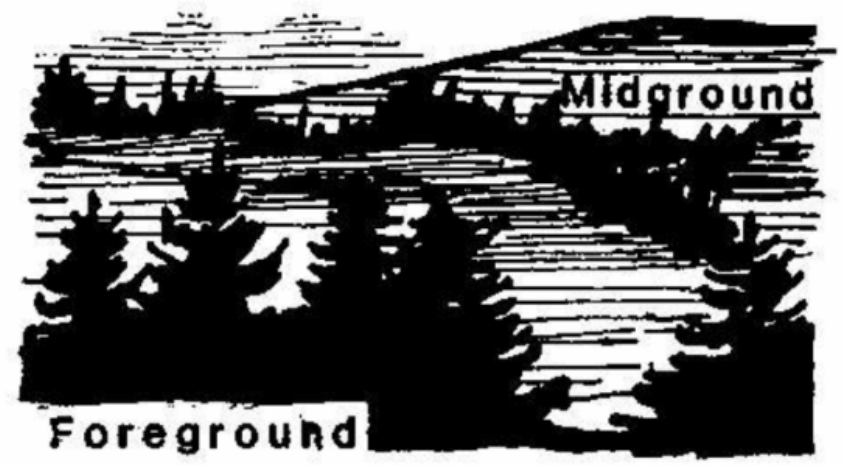

Ryc. 5. Trzy główne strefy widokowe, zaadaptowane z Yeomans' 1983.

Fig. 5. Three main distance zones, Adapted from Yeomans'.

There should be opportunity to observe the closest landscape elements, such as the petals of the flowers, as well as the long distance elements. Even though long-distance views are usually most difficult to achieve for designers, they can be very beneficial for the patients with neurodegenerative diseases. Far views can:

stimulate in the observer a sense of personal freedom, mental pleasure and stress reduction. The need of distant view or in many cases it can be a desire, results from a human nature of a hunter, consolidated in our genes. Fulfilling this desire can be done beyond our will or completely consciously [25].

Another benefit of introducing long distance views is described in a broad study by Bates [4]. This author of alternative therapy aimed at improving eyesight without the use of glasses or lenses. He suggested that nearly all eye problems are caused by the habitual strain of the eyes. Switching the visual attention between the close, middle and far distances, repeatedly and continuously, blinking and relaxing from time to time, may significantly improve one's eyesight quality. The mechanism of switching between the distance zones seem to stress the importance of introducing far vistas in any type of therapeutic garden.

Considering the eye disorders associated with aging, namely age-related degeneration which can induce social withdrawal and avoidance of going outdoors, it is important to minimize the reflectiveness of garden elements, and provide shaded zones as well as the 
transition zone where the brightness gradually intensifies as the patient walks outside. Sitting areas and observation points should always be in shaded areas (the Fig. 1, Fig. 2), as direct exposition to the sun may increase anxiety and induce panic.

\section{PRELIMINARY GUIDELINES}

The most important design guidelines for the therapeutic gardens for patients with NG together with the expected benefits of their use are presented in Table 1. The further benefits of those guidelines include the aforementioned general benefits.

Tab. 1. Guidelines for the designers of therapeutic gardens with the expected benefits.

\begin{tabular}{|c|c|c|}
\hline Category & Specific guideline & Expected benefits \\
\hline Accessibility & Fully accessible in a daytime & \multirow{2}{*}{$\begin{array}{l}\text { Increase sense of independence, per- } \\
\text { sonal freedom }\end{array}$} \\
\hline \multirow{2}{*}{ Views } & $\begin{array}{l}\text { Long-distance views (over } 400 \mathrm{~m} \text { into the } \\
\text { landscape) }\end{array}$ & \\
\hline & $\begin{array}{l}\text { Switching between short and long distance } \\
\text { objects }\end{array}$ & Improving eyesight \\
\hline \multirow{6}{*}{ Compatibility } & $\begin{array}{l}\text { Explicit spatial order, keeping the } \\
\text { design in balance }\end{array}$ & \multirow{4}{*}{$\begin{array}{l}\text { Sense of tranquility, peace and silence, } \\
\text { limiting level of stress, anxiety and limita- } \\
\text { tion, } \\
\text { Attention restoration } \\
\text { Invites to rest and relax outdoors }\end{array}$} \\
\hline & Absence of disturbing elements & \\
\hline & $\begin{array}{l}\text { Openings and closings of views worked out } \\
\text { well }\end{array}$ & \\
\hline & $\begin{array}{l}\text { Harmonious physical and visual relations } \\
\text { between the elements }\end{array}$ & \\
\hline & $\begin{array}{l}\text { Clear communication system and hierarchi- } \\
\text { cal relations between signage elements }\end{array}$ & \multirow{6}{*}{$\begin{array}{l}\text { Reduced risk of getting lost and better } \\
\text { orientation in space }\end{array}$} \\
\hline & Inward orientation of space & \\
\hline \multirow{2}{*}{ Natural mapping } & $\begin{array}{l}\text { Small number of paths visible from every } \\
\text { point in space }\end{array}$ & \\
\hline & Managing accessibility with the ground cover & \\
\hline \multirow{3}{*}{ Landmarks } & $\begin{array}{l}\text { Dominant, scarce elements in the space } \\
\text { easy to relate to }\end{array}$ & \\
\hline & \multirow{2}{*}{$\begin{array}{l}\text { Landmarks in a form of archetypal element } \\
\text { (e.g. single large tree, stone, water-pond, } \\
\text { circle) }\end{array}$} & \\
\hline & & $\begin{array}{l}\text { Identification (felling familiar) with the } \\
\text { space on the deep unconscious level }\end{array}$ \\
\hline Shade \& & Gradual intensification of brightness & Alleviating eye irritation \\
\hline
\end{tabular}


Reflectiveness Limiting the reflectiveness of garden elements

Lack of direct exposition to sun in the resting areas

Feeling of security, limiting overheating

\section{CONCLUSIONS}

As new research approaches emerge, there is an increasing number of findings about how the quality of the built environment can influence peoples' behavior and how beneficial it can be for inpatients of mental-health services. Simultaneously, there is a demand for therapy approaches alternative to commonly used pharmaceuticals to reduce the symptoms of neurodegenerative diseases. For any health-care unit, especially those which deal with mentally ill patients, it is vital to design so-called therapeutic gardens and the literature on this subject is extensive.

Due to that fact that neurodegenerative diseases have a chronic character, it is not expected that the treatment would ever allow patients a full recovery, returning to their homes and day-to-day lives. The specificity of neurodegenerative disease care units is to help alleviate the symptoms of those diseases and help reduce their impact on the patients' caregivers and on their own well-being, in effect, prolonging their life.

Studies have shown that a poorly prepared space can reinforce aggressive and agitative behaviors among patients and, thus, reduce the expected treatment effects which indirectly leads to more resources being spent on their care and treatment. On the other hand, the right design of the surrounding environment can help in limiting those factors. Moreover, the described studies on the behavioral-physiological response to different design strategies suggest that there may be some elements in the designed landscapes that can actually enhance the sense of well-being in patients.

These landscape features (design guidelines) should not be treated as a set of universal rules, as each design approach varies in terms of various factors, and also because there is no one ideal design for any one space, but instead an infinite number of appropriate ones [2]. Nevertheless, the presented design guidelines can successfully inform and inspire the landscape architectural and architectural practice as well as contribute to the growth of the area of evidence-based design.

\section{BIBLIOGRAPHY}

[1] American Psychiatric Association. Diagnostic and statistical manual of mental disorders (DSM-5®). American Psychiatric Pub. 2013, ISBN-10: 0890425558

[2] Archer, L. B. The structure of design processes. Doctoral dissertation, Royal College of Art, London, 1969.

[3] Ballard, Clive G., et al. "Management of agitation and aggression associated with Alzheimer disease." Nature Reviews Neurology, 5 (5), 2009, p. 245-255.

[4] Bates, W. H., Perfect sight without glasses. International Society for the Enhancement of Eyesight, 2004.

[5] Berman, M. G., Jonides, J., Kaplan, S., "The cognitive benefits of interacting with nature". Psychological Science, 19(12), 2008.

[6] Beveridge, C. E., \& Rocheleau, P., Frederick Law Olmsted. Rizzoli International Publications, 1996.

[7] Bil J. Evidence Based Design for contemporary healthcare facilities. Space \& Form. vol. 22(1), 2014, p. 69-80. 
[8] Bredesen DE, Rao RV, Mehlen P. "Cell death in the nervous system". Nature 443 (7113): 796-802. Bibcode:2006Natur.443..796B., October 2006, doi:10.1038/nature05293.

[9] Burns, A; lliffe, S. "Dementia.". BMJ (Clinical research ed.) 338: b75. doi:10.1136/bmj.b75. PMID 19196746, 5 February 2009.

[10] Burns A, lliffe S. "Alzheimer's disease". BMJ 338: b158. February 2009, doi:10.1136/bmj.b158. 5

[11] De Grey, Aubrey D.N.J. "Life Span Extension Research and Public Debate: Societal Considerations". Studies in Ethics, Law, and Technology 1. doi:10.2202/1941-6008.1011, 2007.

[12] "Dementia Fact sheet $N^{\circ} 362$ ". who. int. April 2012. access 2014-11-28.

[13] Dillin A, Gottschling DE, Nyström T; Gottschling; Nyström., "The good and the bad of being connected: the integrons of aging". Curr Opin Cell Biol 26: 107-12. 2014, doi:10.1016/j.ceb.2013.12.003.

[14] Hermann, H. "On the transcendent in landscapes of contemplation" In Contemporary Landscapes of Contemplation. Krinke, R. (Ed), 2005, 36-72.

[15] Jung, C. G., The Archetypes and the Collective Unconscious. Routledge: London, 1955

[16] Kaplan, R., Kaplan, S., Ryan, R., With people in mind: Design and management of everyday nature. Washington DC: Island Press, 1998.

[17] Larson, EB; Yaffe, K; Langa, KM. "New insights into the dementia epidemic". The New England Journal of Medicine 369 (24): 2275-7. 12 December 2013. doi:10.1056/nejmp1311405,

[18] Lopez, Alan D; Mathers, Colin D; Ezzati, Majid; Jamison, Dean T; Murray, Christopher JL. "Global and regional burden of disease and risk factors, 2001: Systematic analysis of population health data". The Lancet 367 (9524): pp. 1747-57. 2006. doi:10.1016/S01406736(06)68770-9.

[19] Lynch, K., The image of the city (Vol. 11). MIT press. 1960.

[20] Norman, D. A., The design of everyday things: Revised and expanded edition. Basic books, 2013

[21] Olszewska A.A., Contemplative values of Urban Parks and Gardens: Applying Neuroscience to Landscape Architecture, PhD thesis, University of Porto, Portugal, 2016.

[22] Perutz MF. Glutamine repeats and inherited neurodegenerative diseases: molecular aspects. Current opinion in structural biology. 1996 Dec 31;6(6):848-58.

[23] Rosen HJ, Allison SC, Schauer GF, Gorno-Tempini ML, Weiner MW, Miller BL. Neuroanatomical correlates of behavioural disorders in dementia. Brain. 2005 Nov 1;128(11):261225.

[24] Rubinsztein DC. "The roles of intracellular protein-degradation pathways in neurodegeneration". Nature 443 (7113): 780-6. Bibcode: 2006Natur.443..780R, October 2006, doi:10.1038/nature05291,

[25] Skalski, J. Comfort of long-distance perceiving and a landscape of river valley in towns situated on the plains. Teka Komisji Architektury, Urbanistyki i Studiów Krajobrazowych, 2005.

[26] Strong R. Neurochemical changes in the aging human brain: implications for behavioral impairment and neurodegenerative disease. Geriatrics. 1998 Sep; pp. 53:S9-12.

[27] Therapeutic Landscapes Network http://www.healinglandscapes.org/ access 2016-05-03.

[28] Tetewsky, S. J., Charles J. D. "Visual loss and getting lost in Alzheimer's disease." Neurology 52.5, 1999, pp. 958-958.

[29] U.S.D.A, Forest Service. National Forest Landscape Management, vol. 1, U.S. Government Printing Office: Washington, D.C, 1973.

[30] Woolley J.D., Khan B.K., Murthy N.K., Miller B.L., Rankin K.P., The diagnostic challenge of psychiatric symptoms in neurodegenerative disease: rates of and risk factors for prior psychiatric diagnosis in patients with early neurodegenerative disease. The Journal of clinical psychiatry. 2011 Feb., 15;72(2):1-478.

[31] World Health Organization. The ICD-10 classification of mental and behavioural disorders: clinical descriptions and diagnostic guidelines. Geneva: World Health Organization; 1992. 
[32] Zeisel, John, et al. "Environmental correlates to behavioral health outcomes in Alzheimer's special care units." The Gerontologist $43.5,2003$ pp. 697-711.

[33] Zeisel, J., Treatment effects of healing gardens for Alzheimer's: A difficult thing to prove. Edinburgh Garden Paper, 2005.

[34] Zgaljardic DJ, Borod JC, Foldi NS, Mattis P. A review of the cognitive and behavioral sequelae of Parkinson's disease: relationship to frontostriatal circuitry. Cognitive and behavioral neurology. 2003 Dec 1;16(4):193-210.

\section{AUTHOR'S NOTE}

AGNIESZKA ANNA OLSZEWSKA, Master in Landscape Architecture from Warsaw University of Life Science, Founder of Terra-Landscape, PhD in Landscape Architecture and Urban Ecology at University of Porto, Portugal. Research interest in application of neuroscience methods in urban planning and landscape architecture practice. Successfully ran a series of EEG experiments on different landscape settings, as a part of her 5-year-long research project titled Contemplative Values of Urban Parks and Gardens, Applying Neuroscience to Landscape Architecture at the University of Porto, Faculty of Science and in collaboration with the Laboratory of Neuro-Psychophysiology at the Faculty of Psychology of the same university. Author's Orcid number: ORCID: 0000-0002-5278-0374

JAKUB S. BIL, Phd Eng Arch, Licensed Arch.,IARP/MPOIA, PTPS, SHL, Adjunct at Andrzej Frycz Modrzewski Kraków University, Faculty of Architecture and Fine Arts. Scientific activity in the following fields: Architecture of psychiatric hospitals, Architecture healthcare facilities, Evidence Based Design for healthcare facilities, Evidence Based Design for mental healthcare, Therapeutic role of the built environment, general healthcare facilities, mental healthcare, Reduction of environmental hazards in hospitals through the modernization of the built environment. Author's Orcid number : 0000-0002$2701-4475$

\section{O AUTORZE}

AGNIESZKA ANNA OLSZEWSKA: Absolwentka Warszawskiej Szkoły Architektury Krajobrazu (SGGW), założycielka studia projektowego Terra-Landscape. Doktorat na Uniwersytecie w trakcie którego z powodzeniem przeprowadziła serię doświadczeń na różnych typach krajobrazu, jako część 5-letniego projektu badawczego zatytułowanego "Wartości Kontemplacyjne Parków i Ogrodów miejskich, zastosowanie Neuropsychofizjologii w Architekturze Krajobrazu" na na Wydziale Nauk Uniwersytetu w Porto oraz we współpracy z Laboratorium NeuroPsychofizjologii na Wydziale Psychologii tejże uczelni. Zainteresowania naukowe skupiają się wokół kontynuowania prac nad metodyką zastosowania metod neuropsychofizjologicznych w praktyce urbanistycznej i architekturze krajobrazu.

JAKUB S. BIL: Praktykujący architekt, adiunkt, zatrudniony na Wydziale Architektury i Sztuk Pięknych Krakowskiej Akademii im. Andrzeja Frycza Modrzewskiego. Członek: MOIA, PTPS i SHL. Prowadzi działalność naukową w zakresie: architektury szpitali psychiatrycznych, architektury obiektów służby zdrowia, Evidence Based Design - projektowania opartego na dowodach naukowych, Evidence Based Design for mental healthcare - projektowania lecznictwa psychiatrycznego opartego na dowodach naukowych, terapeutycznej roli środowiska zbudowanego obiektów służby zdrowia, szczególnie szpitali psychiatrycznych, redukcji zagrożeń w obiektach szpitali poprzez modernizację środowiska zbudowanego.

Kontakt | Contact: olszewska.agn@gmail.com, jacobbil@gmail.com 